\title{
Struktur dan Ciri Kebahasaan Teks Cerita Fantasi dalam Antologi Cerita Fantasi Terbaik 2011 Karya Various dan Implementasinya sebagai Bahan Ajar Siswa SMP/MTs Kelas VII
}

\author{
Abdul Rozak ${ }^{1)}$,Dede Endang Mascita ${ }^{2)}$,Teguh Wilda Jatmiko ${ }^{3)}$ \\ Universitas Swadaya Gunung Jati ${ }^{1), 2)}$, SMP Negeri 1 Kersana Brebes ${ }^{3)}$ \\ Abdurrozak58@gmail.com ${ }^{1)}$, dedenmas68@gmail.com ${ }^{2}$, \\ teguhwildajatmiko@gmail.com ${ }^{3)}$
}

\begin{abstract}
Abstrak. Penelitian ini bertujuan untuk mengetahui struktur dan ciri kebahasaan dalam Antologi Cerita Fantasi Terbaik 2011 karya Various, serta implikasinya untuk mengembangkan bahan ajar digital yang berjudul Mengenal Teks Cerita Fantasi untuk Siswa SMP/MTS Kelas VII. Penelitian ini merupakan penelitian deskriptif analitik. Hasil penelitian pada bagian struktur menemukan bahwa dari 15 cerita fantasi semuanya memiliki struktur orientasi dan resolusi, dua cerita tidak memiliki bagian komplikasi, dan enam cerita memiliki bagian koda. Pada ciri kebahasaan ditemukan penggunaan kata ganti nama orang sebagai penceritaan, penggunaan majas, penggunaan konjungsi, dan penggunaan kalimat langsung. Pengembangan bahan ajar digital menggunakan aplikasi Android Magazine Maker Profesional(AMMP). Bahan ajar ini memiliki keunggulan, diantaranya: adanya fitur gambar, suara, dan video pembelajaran serta ikon penunjang yang menjadikan bahan ajar lebih menarik untuk digunakan. Hasil validasi ahli membuktikan bahwa bahan ajar digital yang berjudul Mengenal Teks Cerita Fantasi untuk Siswa SMP/MTs Kelas VII dinyatakan layak dan dapat digunakan sebagai bahan penunjang dalam proses pembelajaran. Hal itu didasarkan pada data hasil angket respons siswa yang memperoleh skor rata-rata sebesar 4,13 dengan persentase $82,64 \%$ yang termasuk dalam kategori "baik".
\end{abstract}

Kata kunci: cerita fantasi, struktur teks, ciri kebahasaan, bahan ajar digital

\section{Pendahuluan}

Perkembangan teknologi semakin pesat. Termasuk perkembangan teknologi pendidikan. Teknologi pendidikan adalah suatu hal yang tidak bisa dihindari dan harus dihadapi oleh dunia pendidikan. Dunia pendidikan harus bisa beradaptasi dengan kemajuan teknologi. Dengan demikian, dunia pendidikan sebagai wahana untuk mendidik dan mengembangkan sumber daya manusia dapat menjalankan fungsinya dengan baik.

Pendidik dan peserta didik yang ada di lingkungan pendidikan semakin akrab dengan perkembangan teknologi tersebut. Khususnya perkembangan telepon pintar (smartphone).

Di tengah pesatnya kemajuan teknologi dan gencarnya arus globalisasi, ada kabar baik dari dunia literasi khususnya di Indonesia. Kabar baik tersebut adalah Meningkatnya kegiatan masyarakat dalam hal membaca. Atmaja (2012) menyebutkan bahwa peningkatan kualitas terlihat dari munculnya buku-buku fiksi, salah satu jenis fiksi yang mulai mendapat perhatian masyarakat ialah jenis cerita fantasi.

Cerita fantasi digemari berbagai macam usia mulai dari kategori anak-anak, remaja, hingga dewasa. Usia 10-13 tahun merupakan masa peralihan dari anak-anak menuju remaja (Hasibuan, 2008). Usia tersebut sama dengan usia sekolah ksususnya tingkat menengah pertama (SMP). Pada usia-usia tersebut daya imajinasi dan kreativitas anak sedang berkembang (Sanjaya, 2017). Selain itu, membaca cerita fantasi sangat penting bagi masa 
perkembangan anak. Jenjang SMP adalah masa peralihan dari anak-anak menuju remaja, anak usia 12-13 tahun umumnya duduk di kelas VII. Salah satu mata pelajaran yang mereka pelajari adalah Bahasa Indonesia. Andayani (2015) menjelaskan materi pembelajaran bahasa Indonesia di tingkat SMP di dalam kurikulum 2013 terdiri atas: teks jenis laporan observasi; teks tanggapan deskriptif; teks eksposisi; teks eksplanasi; teks cerita pendek; analisis dan evaluasi teks.

Dalam kurikulum 2013 edisi revisi tahun 2016, menyajikan salah satu materi ajar sastra yang berkaitan dengan fiksi berjenis fantasi yaitu materi teks cerita fantasi. Hal ini sesuai dengan penelitian yang dilakukan oleh Fajria (2017) yang menyimpulkan bahwa teks cerita fantasi termasuk salah satu bentuk teks narasi yang merupakan materi yang terdapat pada kurikulum 2013 edisi revisi.

Buku pegangan siswa yang diterbitkan oleh kemendikbud menjadi fasilitas dalam kegiatan belajar dan mengajar berkaitan dengan teks cerita fantasi. Dalam penyajian materi teks cerita fantasi sebenarnya sudah ada. Namun, untuk terus meningkatkan minat baca dan antusiasme siswa dalam mempelajari teks cerita fantasi perlu adanya penambahan kedalaman materi dan penyajian contoh teks cerita fantasi yang lebih baru sehingga dapat dicapai tujuan pembelajaran yang diharapkan. Hal ini sesuai dengan penelitian yang dilakukan oleh Gunawan (2016) yang menemukan fakta di lapangan, bahwa siswa sebetulnya tertarik dengan pembelajaran sastra.

Salah satu cara yang dapat dilakukan oleh guru dalam rangka menjaga minat siswa dalam kegiatan pembelajaran ialah dengan menyusun bahan ajar yang disesuaikan dengan kondisi dan kebutuhan siswa sehingga diharapkan tujuan pembelajaran dapat tercapai. Hal ini sesuai dengan pendapat Mudlofir (2013) dalam penelitianya menyebutkan bahwa bahan ajar memiliki peran yang krusial dan begitu penting dalam proses belajar dan mengajar.

Keberadaan bahan ajar sastra sangat penting bagi guru dan siswa. Maka, penyusunan bahan ajar sastra perlu dilakukan untuk memperdalam kajian materi sastra dalam proses pembelajaran. Penyusunan bahan ajar yang baik perlu memperhatikan kondisi dan kebutuhan siswa. Melalui analisis kurikulum, maupun analisis kompetensi inti dan kompetensi dasar. Hal ini sesuai dengan pendapat Rozak (2014) menemukan fakta bahwa jika diihat dari porsinya sajian materi sastra sangat minimalis. Apa yang ada dalam lingkup sastra tidak terwakili dalam K13. Keluasan dan kedalaman materi sastra sangat sulit dikaitkan dengan kehendak K13.

Jika melihat bahan ajar sastra yang ada, sampai saat ini bahan ajar yang dirancang merupakan bahan ajar yang berbentuk cetak, misalnya modul, lembar kerja siswa, ataupun buku. Hal ini sesuai dengan yang dikemukakan oleh Prastowo (2013) bahwa bentuk bahan ajar cetak antara lain handout, buku, modul, dan lembar kerja siswa. Akan tetapi, di era kecanggihan teknologi saat ini perlu adanya pembaruan sehingga proses pembelajaran menjadi lebih menarik. Perkembangan teknologi dan informasi dewasa ini sangatlah pesat. Pesatnya kemajuan teknologi juga turut dirasakan oleh dunia pendidikan. Salah satu hal positif dari perkembangan teknologi ialah kemunculan sebuah bahan ajar digital (Tompo, 2016).

Melihat permasalahan yang dihadapi oleh siswa dengan masih terbatasnya fasilitas belajar dalam hal ini bahan ajar materi sastra khususnya teks cerita fantasi. Begitu juga 
permasalahan yang dihadapi oleh guru ketika menyampaikan materi teks cerita fantasi. Dalam Penelitian ini penulis merancang sebuah bahan ajar teks cerita fantasi berbasis digital pada tingkat SMP khususnya kelas VII. Penyusunan bahan ajar digital diharapkan dapat memotivasi, memudahkan, serta memberikan dampak positif penggunaan telepon pintar bagi siswa dan guru.

\section{Metode}

Metode penelitian yang digunakan yakni deskriptif analitik dan desain pengembangan model ADDIE.Penelitian deskriptif analitik dilakukan dengan cara mendeskripsikan faktafakta yang kemudian disusul dengan analisis. Kemudian memberikan pemahaman dan penjelasan secukupnya (Ratna, 2013). Penelitian diawali dengan menganalisis buku berjudul Antologi Cerita Fantasi Terbaik 2011 karya Various. Kemudian hasil analisis diplih dan dijadikan sebagai bahan teks bacaan dalam bahan ajar yang dikembangkan. Bahan ajar yang dimaksud adalah produk bahan ajar digital teks cerita fantasi untuk kelas VII. Desain pengembangan ADDIE digunakan untuk pengembangan produk bahan ajar yang terdiri dari lima tahap, yaitu (Analysis) menganalisis,(Design),merancang (Develop-ment) mengembangkan, (implementation) mengimplementasikan, dan (Evaluation) mengevaluasi (Rozalena, 2016). Melalui tahapan tersebut maka dihasilkan sebuah bahan ajar digital yang kemudian divalidasi oleh para ahli dan praktisi pembelajaran, hingga pada akhirnya di implementasikan pada pembelajaran Bahasa Indonesia di SMP, dengan target sasaran siswa SMP kelas VII untuk mengetahui kelayakan bahan ajar yang digunakan. Berikut adalah diagramalirpenelitiandeskriptifkualitatif yang digunakan

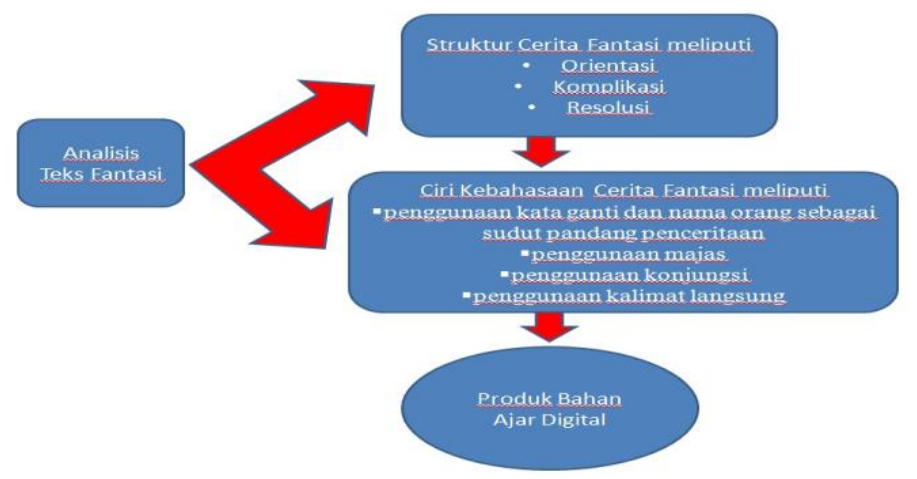

Wujud data penelitian berupa buku Fantasy Fiesta 2011 Antologi Cerita Fantasi Terbaik 2011 Karya Various oleh penerbit Adhika Pustaka, Jakarta, pada tahun 2011. Sedangkan responden dalam penelitian ini adalah siswa kelas VII yaitu kelas VII a yang terdiri dari 22 siswa di SMP NU Bustanul Ulum Jatirokeh Songgom Brebes.

Teknik pengumpulan data yang akan digunakan dalam penelitian ini adalah teknik baca dan catat. Disebutkan oleh Ratna (2013) dalam sebuah penelitian perlu adanya proses membaca untuk memperoleh data yang diharapkan.

Selanjutnya teknik pengumpulan data dalam proses penyusunan bahan ajar mencakup data kualitatif dan kuantitatif, data kualitatif merupakan data tentang proses pengembangan bahan ajar berupa saran dan komentar dari ahli materi, ahli bahan ajar, praktisi pembelajaran, dan peserta didik. Sedangkan data kuantitatif merupakan data pokok dalam penelitian berupa

Abdul Rozak, Dede Endang Mascita, Teguh Wilda Jatmiko | Struktur dan Ciri Kebahasaan Teks Cerita Fantasi dalam Antologi Cerita Fantasi Terbaik 2011 Karya Various dan Implementasinya Sebagai Bahan Ajar Siswa SMP/MTs Kelas VII | 
data penilaian kelayakan bahan ajar berupa skor/angka dari ahli materi, ahli bahan ajar, praktisi pembelajaran, dan peserta didik yang berkaitan dengan bahan ajar yang dikembangkan.

Pengumpulan data menggunakan dua buah instrumen, instrumen yang pertama yaitu teknik mencatat data yang merupakan lanjutan dari tahap menyimak pada sebuah kartu data. Kartu data disajikan dalam bentuk tabel yang terdiri dari lajur dan kolom yang diisi oleh penulis (Mahsun 2014). Penggunaan kartu data dalam penelitian ini bertujuan untuk mengumpulkan data analisis struktur cerita fantasi dan ciri kebahasaan dalam buku Antologi Cerita Fantasi Terbaik 2011. Berupa wacana atau pernyataan yang digunakan oleh tokoh dalam cerita.

Instrumen kedua adalah angket, angket merupakan teknik pengumpulan data yang dilakukan dengan cara memberi seperangkat pertanyaan tertulis kepada responden (Sugiyono, 2011). Responden dalam penelitian ini adalah siswa, ahli materi, praktisi pembelajaran, dan ahli media. Angket ini bertujuan untuk mengetahui kualitas dari bahan ajar teks cerita fantasi berbasis digital dari beberapa aspek yaitu aspek materi, konstruksi, bahasa, rekayasa perangkat lunak, dan komunikasi visual.

Penilaian kelayakan bahan ajar dilakukan melalui penghitungan hasil pekerjaan siswa dan akumulasi skor uji validasi dan respons siswa.

\section{Hasil dan Pembahasan}

a. Struktur Teks Cerita Fantasi

Analisis struktur dan kaidah kebahasaan dilakukan terhadap buku yang berjudul Antologi Cerita Fantasi Terbaik 2011 karya Various. Sebanyak 15 judul cerita dianalisis berdasarkan struktur dan ciri kebahasaaannya, analisis struktur meliputi orientasi, komplikasi, dan resolusi.

Secara umum struktur teks cerita fantasi terdiri dari orientasi, komplikasi dan resolusi. Dari kelima belas cerita yang telah dianalisis terdapat dua cerita yang tidak memiliki struktur komplikasi yaitu pada cerita berjudul "Bhupendra Gagan" dan "Kembali ke Morova", selebihnya ketiga belas cerita lainnya memiliki struktur cerita yang utuh mulai dari orientasi, komplikasi dan resolusi. Pada struktur orientasi dari kelima belas cerita yang dianalisis secara keseluruhan kelima belas cerita memiliki sruktur orientasi atau sejumlah (100\%).

Struktur komplikasi dari kelima belas cerita yang dianalisis sejumlah $(13,3 \%)$ yang terdiri dari dua cerita yang tidak memiliki struktur komplikasi, selebihnya ketiga belas cerita atau $(86,6 \%)$ memiliki struktur komplikasi.

Berikutnya struktur resolusi, dari kelima belas cerita yang dianalisis seluruh cerita memiliki struktur resolusi atau sejumlah (100\%). Setelah dilakukan analisis struktur cerita fantasi terhadap lima belas judul cerita yang dipilih. Kemudian diperoleh hasil analisis data bahwa terdapat struktur tambahan di luar teori struktur cerita fantasi yang meliputi orientasi, komplikasi, dan resolusi yaitu adanya struktur koda. Srtuktur koda pada umumnya berada pada bagian akhir dalam cerita karena fungsinya sebagai pemberi pesan atau amanat kepada pembaca, dari lima belas judul cerita yang dianalisis terdapat sembilan judul cerita atau sebesar $(60 \%)$ yang memiliki struktur koda. Kesembilan judul cerita yang memiliki struktur 
koda yaitu Bhupendra Gagan, Dongeng Kanvas, Enam Belas Menit, Hari Terakhir Ishan, Kembali ke Morova, Misteri Pulau Goudian, Neil| Lien, Oris, dan Petra.

\section{b. Ciri Kebahasaan Teks Cerita Fantasi}

Hasil analisis ciri kebahasaan meliputi empat komponen yang terdiri dari penggunaan kata ganti dan nama orang sebagai sudut pandang penceritaan, penggunaan majas, penggunaan konjungsi, dan penggunaan kalimat langsung. Dari kelima belas cerita yang dianalisis keseluruhan cerita memiliki keempat komponen ciri kebahasaan yang telah disebutkan. Masing-masing cerita memiliki ciri kebahasaan yang khas, namun dapat digeneralisasikan. Berdasarkan hasil analisis ciri kebahasaan terkait dengan penggunaan kata ganti dan nama orang sebagai sudut pandang penceritaan secara umum kelima belas cerita menggunakan tiga jenis kata ganti atau sudut pandang penceritaan, yaitu sudut pandang orang pertama, sudut pandang orang ketiga serba tahu, dan sudut pandang orang ketiga objektif.

Selanjutnya penggunaan majas, berdasarkan hasil analisis kelima belas cerita. Secara umum terdapat tiga jenis majas yang digunakan yaitu majas personifikasi, majas metafora, dan majas hiperbola.

Berikutnya analisis ciri kebahasaan berdasarkan aspek penggunaan konjungsi, berdasarkan hasil analisis kelima belas cerita, secara umum jenis konjungsi yang digunakan dibagi menjadi dua jenis yaitu konjungsi intrakalimat dan konjungsi antarkalimat. Dari kelima belas cerita yang dianalisis penggunaan konjungsi intrakalimat terdiri dari 27 kata yang secara umum menggunakan kata-kata berikut, (walau, dengan, hingga, jika, sebagai, setelah, karena, ketika, agar, sambil, bahwa, hanya, kalau, meski, sehingga, sejak, jikalau, sekalipun, seolaholah, seaindainya, supaya, biarpun, biar, seperti, sampai, seakan-akan, seandainya). Sedangkan penggunaan konjungsi antarkalimat terdiri dari 13 kata yang secara umum menggunakan kata-kata berikut, (namun, bahkan, demikian, begitupun, bahkan, walaupun, oleh karena, lagi pula, walaupun demikian, sebaliknya, selanjutnya, lagi pula, sesungguhnya).

Analisis ciri kebahasaan yang terakhir ialah penggunaan kalimat langsung berdasarkan hasil analisis kelima belas cerita. Secara umum seluruh cerita menggunakan kalimat langsung atau sejumlah (100\%).

Hasil analisis struktur cerita fantasi dan ciri kebahasaan dalam buku Antologi Cerita Fantasi Terbaik 2011 karya Various diuraikan dalam bentuk data tabel rekapitulasi sebagai berikut.

Tabel 4. Data rekapitulasi analisis sturktur cerita fantasi dan ciri kebahasaan dalam Antologi Cerita Fantasi Terbaik 2011 karya Various.

\begin{tabular}{ll}
\hline \multicolumn{2}{c}{ Komponen Aspek } \\
Struktur Teks
\end{tabular}


2. Komplikasi

3. Resolusi

4. Koda (di luar teori struktur cerita fantasi dan termasuk ke dalam sebuah temuan penelitian)
- Terdapat dua cerita yang tidak memiliki bagian komplikasi

- Penjelasan singkat tentang munculnya sebabakibat

- Tokoh utama menemui permasalahan baik dari dalam (konflik batin) atau dari luar (tokoh yang lain)

- Menjelaskan terjadinya proses pemecahan permasalahan yang dihadapi oleh tokoh utama dalam cerita

- Berisi sebab- akibat yan memuncukan konflik dalam cerita

- Konflik menuju puncak permasalahan dalam cerita (klimaks)

- Kelima belas cerita memiliki bagian resolusi

- Berisi solusi

- Berisi akhir cerita berupa nasib yang dialami oleh tokoh utama

- Cerita diakhiri dengan (bahagia dan kesedihan)

- Terdapat sembilan judul cerita yang memiliki bagian koda.

\section{Ciri Kebahasaan}

1. Penggunaan Kata ganti dan nama orang sebagai sudut pandang penceritaan

2. Penggunaan Majas

3. Penggunaan Konjungsi
- $\quad$ Orang pertama (8 cerita )

- Orang ketiga serba tahu (13 cerita)

- Orang ketiga objektif (2 cerita)

- Majas personifikasi (32 kalimat)

- Majas metafora (51 kalimat)

- Majas hiperbola (19 kalimat)

- Konjungsi Intrakalimat (walau, dengan, hingga, sebagai, setelah, karena, jika, ketika, agar, sambil, bahwa, hanya, kalau, meski, sehingga, sejak, jikalau, sekalipun, seolaholah, seaindainya, supaya, biarpun, biar, seperti, sampai, seakan-akan, seandainya)

- Konjungsi antarkalimat (namun, bahkan, demikian, begitupun, bahkan, walaupun, oleh karena, lagi pula, walaupun demikian, sebaliknya, selanjutnya, lagi pula, sesungguhnya)

- Seluruh cerita menggunakan kalimat langsung

Data tabel 4 menunjukkan hasil analisis terhadap 15 cerita fantasi dengan fokus analisis struktur teks dan ciri kebahasannya. Secara umum terdapat kesamaan pola dari bagian struktur dan ciri kebahasaannya, sedangkan bagian isi maupun jalan cerita sangat tampak perbedaannya pada tema yang dibahas pada cerita itu.

\section{c. Hasil Implementasi Bahan Ajar}

Bahan ajar teks cerita fantasi ini memanfaatkan sebuah aplikasi bernama AMMP, aplikasi AMMP dipilih karena sesuai dengan kebutuhan pengembangan bahan ajar. Melalui proses pengembangan bahan ajar diperoleh sebuah bahan ajar yang sesuai dengan kebutuhan 
pembaca. Pengembangan yang terjadi pada bahan ajar diantaranya tersedianya ilustrasi berupa gambar pada bagian materi teks cerita fantasi yang disesuikan dengan topik yang dibahas. Sebelum dilakukan pengembangan, materi teks cerita fantasi hanya berupa teks bacaan. Selanjutnya bahan ajar yang dikembangkan juga memiliki sejumlah fitur unggulan yang kemudian menjadi daya tarik bagi pembaca. Sejumlah fitur yang disematkan pada bahan ajar ini diantaranya yaitu fitur suara, dengan adanya fitur suara bahan ajar ini menjadi lebih menarik karena pembaca dapat mengetahui poin penting dari materi yang dibaca. Sebelum dilakukan pengembangan, bahan ajar belum dilengkapi fitur suara dan hanya berupa teks. Selanjutnya, bahan ajar ini dilengkapi dengan video pembelajaran pada materi teks cerita fantasi, serta dilengkapi dengan materi, soal berupa tugas dan evaluasi sehingga memudahkan siswa ketika mempelajari materi teks cerita fantasi. Penambahan video pembelajaran merupakan tahapan pengembangan yang dilakukan sehingga pembelajaran lebih komunikatif. Selain sejumlah fitur yang disebutkan, ada beberapa hal yang menjadi keunggulan bahan ajar yang dikembangkan diantaranya yaitu, bahan ajar yang dikembangkan dapat digunakan pada semua merek telepon pintar berbasis android, dapat dioperasikan dengan mudah, pemasangan dan pencopotoan aplikasi serta pemeliharaan aplikasi mudah dilakukan, pada bagian isi mengutamakan kenyamanan pengguna, dengan adanya fungsi ikon penunjang yang membantu pembaca ketika mengakses bahan ajar, tersedianya ikon pencarian, penanda halaman, penangkap layar, serta tombol aktif dan non-aktifkan suara semakin memudahkan pembaca ketika menggunakan aplikasi bahan ajar digital ini.

Uji coba terbatas diikuti oleh 22 siswa sebagai responden. Sebagai responden siswa diberikan sebuah angket yang terdiri dari empat aspek penilaian yaitu aspek materi, konstruksi, bahasa, dan rekayasa perangkat lunak. Setelah siswa mengisi angket penilaian maka siswa memberikan respons yang sangat baik dengan adanya bahan ajar yang dikembangkan. Siswa menganggap bahan ajar berjudul Mengenal Teks Cerita Fantasi untuk Siswa SMP/MTs Kelas VII sangat membantu proses pembelajaran. Hal tersebut dibuktikan dengan hasil uji coba terbatas dari ke 22 siswa yang memperoleh skor rata-rata tiap aspek yaitu aspek materi memperoleh skor rata-rata 4,40, aspek konstruksi diperoleh skor rata-rata 4,25, aspek bahasa diperoleh skor rata-rata 4,13, dan aspek rekayasa perangkat lunak diperoleh skor rata-rata 4,5. Secara keseluruhan aspek diperoleh skor rata-rata sebesar 4,32 dengan kategori sangat baik. Jika dilihat dari segi persentase maka diperoleh skor sebesar 86,4\%. Dengan demikan, bahan ajar digital dikatakan sangat layak digunakan apabila dilihat dari segi kelayakan bahan ajar.

Hasil implementasi kelayakan bahan ajar yang digunakan, dapat diketahui melalui data diagram 2 pada hasil penelitian. Diketahui skor dari tiap aspek yaitu aspek materi, konstruksi, bahasa, rekayasa perangkat lunak, dan komunikasi visual yang apabila dideskripsikan sebagai berikut.

\section{1) Aspek materi}

Bahan ajar berjudul Mengenal Teks Cerita Fantasi untuk Siswa SMP/MTs Kelas VII ini,pada aspek materi memperoleh skor rata-rata dari ahli materi sebesar 4,00 dengan kategori "baik". Penilaian dilakukan oleh praktisi pembelajaran dan diperoleh skor rata-rata sebesar 4,1 dengan kategori "baik". Sedangkan dari uji coba terbatas 22 siswa diperoleh skor rata-rata sebesar 4,00 dengan kategori "baik". Dari ketiga nilai tersebut, diperoleh skor rata-rata 
sebesar 4,00 dengan persentase 80,67\%. Dengan demikian, bahan ajar berjudul Mengenal Teks Cerita Fantasi untuk Siswa SMP/MTs Kelas VII pada aspek materi dinyatakan layak.

\section{2) Aspek Konstruksi}

Skor rata-rata pada aspek konstruksi dari ahli materi sebesar 4,00 dengan kateogori "baik". Penilaian dari praktisi pembelajaran diperoleh skor rata-rata sebesar 4,00 dengan kategori "baik". Hasil uji coba terbatas 22 siswa diperoleh skor rata-rata sebesar 4,25 dengan kategori "sangat baik". Dari ketiga nilai tersebut, diperoleh skor rata-rata sebesar 4,1 dengan persentase 81,67\%. Dengan demikian, bahan ajar berjudul Mengenal Teks Cerita Fantasi untuk Siswa SMP/MTs Kelas VII pada aspek materi dinyatakan layak.

\section{3) Aspek Bahasa}

Penilaian pada aspek bahasa dilakukan oleh ahli materi dan diperoleh skor rata-rata sebesar 4,11 dengan kategori "baik". Penilaian dari praktisi pembelajaran diperoleh skor ratarata sebesar 4,00. Penilaian yang dilakukan oleh ahli media diperoleh skor rata-rata sebesar 4,00. Sedangkan dari hasil uji coba terbatas 22 siswa diperoleh skor rata-rata sebesar 4,13 dengan kategori "baik". Dari keempat nilai tersebut, diperoleh skor rata-rata sebesar 4,1 dengan persentase 81,2\%. Dengan demikian, bahan ajar berjudul Mengenal Teks Cerita Fantasi untuk Siswa SMP/MTs Kelas VII pada aspek materi dinyatakan layak.

\section{4) Aspek Rekayasa Perangkat Lunak}

Skor rata-rata pada aspek rakayasa perangkat lunak dari ahli media sebesar 4,37 dengan kateogori "sangat baik". Sedangkan dari hasil uji coba terbatas 22 siswa diperoleh skor rata-rata sebesar 4,5 dengan kategori "sangat baik". Dari kedua nilai tersebut, diperoleh skor rata-rata sebesar 4,43 dengan persentase $88,7 \%$. Dengan demikian, bahan ajar berjudul Mengenal Teks Cerita Fantasi untuk Siswa SMP/MTs Kelas VII pada aspek materi dinyatakan sangat layak.

\section{5) Aspek Komunikasi Visual}

Penilaian pada aspek komunikasi visual yang dilakukan oleh ahli media diperoleh skor rata-rata sebesar 4,00 dengan kategori "baik". Dari penilaian tersebut, diperoleh skor rata-rata sebesar 4,00 dengan persentase 80\%. Dengan demikian, bahan ajar berjudul Mengenal Teks Cerita Fantasi untuk Siswa SMP/MTs Kelas VII pada aspek materi dinyatakan layak.

Melalui hasil akumulasi skor rata-rata yang diperoleh dari ahli materi, praktisi pembelajaran, ahli media, dan siswa pada bahan ajar digital berjudul Mengenal Teks Cerita Fantasi untuk Siswa SMP/MTs Kelas VII yaitu, aspek materi, memperoleh skor rata-rata sebesa 4,03 dengan kategori "baik", aspek konstruksi memperoleh skor rata-rata sebesar 4,1 dengan kategori "baik", aspek bahasa memperoleh skor rata-rata sebesar 4,1 dengan kategori "baik", aspek rekayasa perangkat lunak sebesar 4,43 dengan kategori "sangat baik", aspek komunikasi visual memperoleh skor rata-rata sebesar 4,00 dengan kategori "baik". Apabila kelima skor dari kelima aspek itu diakumulasikan, maka bahan ajar digital berjudul Mengenal Teks Cerita Fantasi untuk Siswa SMP/MTs Kelas VII memperoleh skor rata-rata sebesar 4,13 dengan Persentase kelayakan sebesar 82,64\%. 
Berdasarkan skor keseluruhan aspek tersebut di atas, maka bahan ajar berjudul Mengenal Teks Cerita Fantasi untuk Siswa SMP/MTs Kelas VII layak digunakan dalam pembelajaran Bahasa Indonesia SMP/MTs Kelas VII.

Berikut ini adalah diagram batang yang menunjukkan data kelayakan bahan ajar.

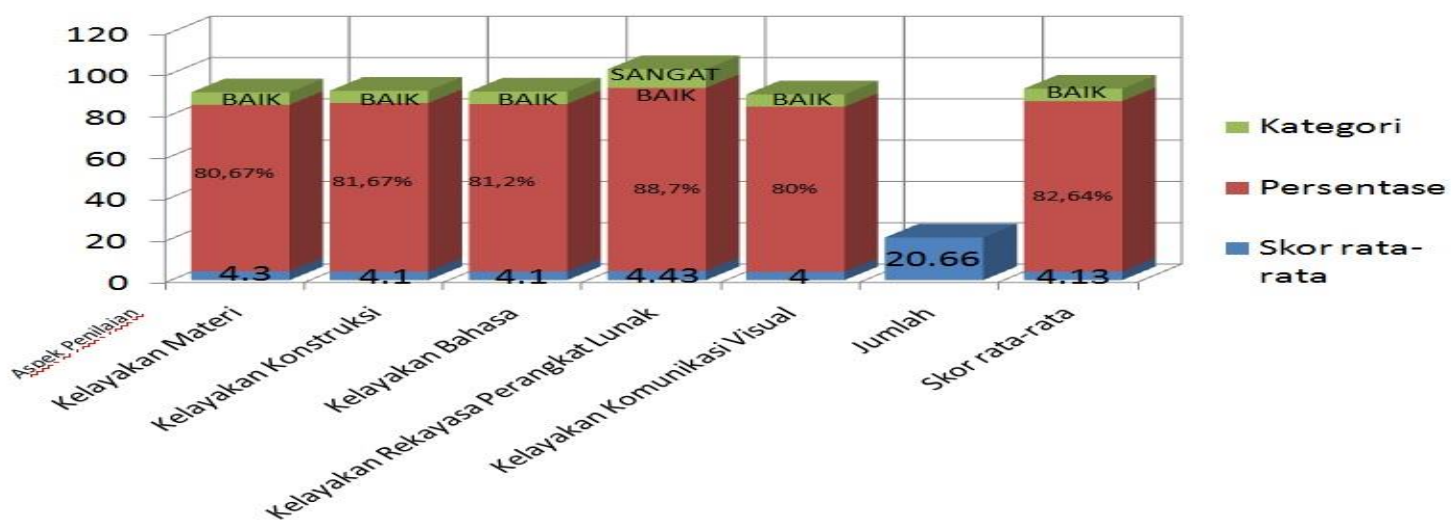

Gambar Diagram 2

Hasil pekerjaan siswa digunakan untuk mengertahui kelayakan bahan ajar digital yang dikembangkan. Hasil pekerjaan siswa diambil dari soal evaluasi yang terdapat dalam bahan ajar digital. Soal evaluasi terdiri dari 10 butir pertanyaan soal pilihan ganda. Dari 22 siswa yang mengikuti pengerjaan soal evaluasi. Diperoleh hasil yang tergambar pada tabel 5 yaitu, sebanyak 18 siswa dinyatakan tuntas dalam menjawab

soal plihan ganda yang diujikan, karena memperoleh nilai di atas KKM mata pelajaran Bahasa Indonesia pada materi pokok Teks Cerita Fantasi yaitu 71.

Melalui tabel 5 diperoleh presentase sebesar 81,81\% dengan kategori "efektif'. Dengan demikian, maka bahan ajar yang dikembangkan dinyatakan layak digunakan apabila persentase dari hasil pekerjaan siswa setidaknya mencapai kriteria efektif

\begin{tabular}{clccc}
\hline No & Nama Peserta Didik & Nilai & KKM=71 & Kriteria \\
\hline 1 & Siswa 1 & 90 & $>$ & Tuntas \\
2 & Siswa 2 & 80 & $>$ & Tuntas \\
3 & Siswa 3 & 80 & $>$ & Tuntas \\
4 & Siswa 4 & 80 & $>$ & Tuntas \\
5 & Siswa 5 & 80 & $>$ & Tuntas \\
6 & Siswa 6 & 60 & $>$ & Belum Tuntas \\
7 & Siswa 7 & 90 & $>$ & Tuntas \\
8 & Siswa 8 & 80 & $>$ & Tuntas \\
9 & Siswa 9 & 90 & $>$ & Tuntas \\
10 & Siswa 10 & 80 & $>$ & Tuntas \\
11 & Siswa 11 & 80 & Tuntas \\
12 & Siswa 12 & 80 & $>$ & Belum Tuntas \\
13 & Siswa 13 & 70 & Tuntas \\
14 & Siswa 14 & 80 & Tuntas \\
15 & Siswa 15 & 90 & Tuntas \\
16 & Siswa 16 & 80 & & \\
\hline
\end{tabular}

Abdul Rozak, Dede Endang Mascita, Teguh Wilda Jatmiko | Struktur dan Ciri Kebahasaan Teks Cerita Fantasi dalam Antologi Cerita Fantasi Terbaik 2011 Karya Various dan Implementasinya Sebagai Bahan Ajar Siswa SMP/MTs Kelas VII | 


\begin{tabular}{|c|c|c|c|c|}
\hline$\infty$ & \multicolumn{4}{|c|}{ Deiksis: Jurnal Pendidikan Bahasa dan Sastra Indonesia, 7 (1) Januari 2020} \\
\hline 17 & Siswa 17 & 70 & $<$ & Belum Tuntas \\
\hline 18 & Siswa 18 & 80 & $>$ & Tuntas \\
\hline 19 & Siswa 19 & 80 & $>$ & Tuntas \\
\hline 20 & Siswa 20 & 90 & $>$ & Tuntas \\
\hline 21 & Siswa 21 & 70 & $<$ & Belum Tuntas \\
\hline 22 & Siswa 22 & 80 & $>$ & Tuntas \\
\hline \multirow{2}{*}{\multicolumn{2}{|c|}{$\begin{array}{l}\text { Persentase } \\
\text { Kateoori }\end{array}$}} & $81,81 \%$ & & \\
\hline & Kategori & Baik & & \\
\hline
\end{tabular}

Presentase Ketuntasan Siswa $=\frac{\text { Banyak siswa tuntas } . X 100}{\text { Jumlah peserta soal Evaluasi }}$
$\frac{18}{22}=81,81 \%$

\section{Pembahasan}

a. Struktur Teks Cerita Fantasi

Berdasarkan hasil analisis struktur teks cerita fantasi terhadap cerita fantasi yang ada pada Antologi Cerita Fantasi Terbaik 2011 Karya Various menunjukkan bahwa tidak semua teks cerita fantasi berstruktur lengkap terdiri atas orientasi, komplikasi, resolusi, dan koda. Tentu saja temuan ini menggambarkan bahwa proses kreatif penciptaan cerita ini tidak selalu memperhatikan struktur. Struktur cerita muncul ketika ada pembaca yang menganalisis unsurunsur struktur tersebut.

Temuan tentang struktur tersebut menjadikan bahan pembelajaran menyusun atau mengontruksi teks cerita fantasi. Siswa bisa diperkenalkan kepada struktur tersebut, tetapi proses kreatif tidak tergantung pada struktur itu. Oleh karena itu, pembelajaran teks cerita fantasi materi struktur teks bisa dimanfaatkan untuk kompetensi dasar pengetahuan. Pada kompetensi dasar keterampilan struktur teks hanya sekedar rambu-rambu atau kerangka sebuah cerita, sedangkan pengembangannya tergantung pada gagasan dan kreatifitas pengarangnya.

\section{b. Ciri Kebahasaan Teks Cerita Fantasi}

Ciri kebahasaan teks cerita fantasi yang ditemukan dari hasil analisis tersebut adalah: 1) penggunaan kata ganti dan nama orang sebagai sudut pandang penceritaan; 2) penggunaan majas; 3) penggunaan kon-jungsi; dan 4) penggunaan kalimat langsung. Temuan tersebut menunjukkan bahwa cerita teks fantasi sangat mempehatikan keindahan bahasa dan kejelasan tokohnya sebagai penggerak cerita.

Ciri kebahasaan dalam pembelajaran menjadi materi kompetensi pengetahuan dan keterampilan. Hal itu dikarenakan pengetahuan tentang ciri kebahasaan akan menuntun siswa ketika menyusun cerita fantasi atau mengidentifikasi cerita fantasi. 
c. Implementasi Bahan Ajar Teks Cerita Fantasi

Hasil implementasi penggunaan bahan ajar di SMP BU NU Jatirokeh Songgom pada siswa Kelas VII, setelah dilakukan penerapan bahan ajar di kelas, siswa memberikan respon yang positif. Hal ini ditandai dengan meningkatnya antusiasme siswa ketika mempelajari materi teks cerita fantasi menggunakan bahan ajar digital yang dikembangkan, kemudian siswa menjadi lebih termotivasi dalam belajar dan terlihat lebih aktif bertanya kepada guru. Setelah implementasi bahan ajar selesai dilakukan, kemudian dilanjutkan pada tahapan pengerjaan soal evaluasi untuk mengetahui keefektifan bahan ajar. Hasil pekerjaan siswa memperoleh nilai sebagai berikut.

\section{Simpulan}

Berdasarkan data hasil penelitian dan pembahasan yang telah diuraikan, penelitian ini menghasilkan sebuah produk bahan ajar digital berjudul Mengenal Teks Cerita Fantasi untuk Siswa SMP/MTs Kelas VII, maka diperoleh kesimpulan sebagai berikut.

Hasil analisis struktur dalam dalam buku Antologi Cerita Fantasi Terbaik 2011 Karya Various. Kelima belas judul cerita mempunyai struktur yang utuh apabila dilihat dari struktur orientasi, kemudian pada struktur komplikasi terdapat dua judul cerita yang tidak memiliki struktur komplikasi, sedangkan pada struktur resolusi kelima belas cerita memiliki struktur resolusi.

Hasil analisis analisis ciri kebahasaan dalam dalam buku Antologi Cerita Fantasi Terbaik 2011 Karya Various. Kelima belas cerita yang dianalisis memiliki ciri kebahasaan yang utuh.

Bahan ajar digital dikembangkan sesuai dengan kebutuhan pembaca, pemasangan dan penggunaan bahan ajar mudah dilakukan. Keunggulan bahan ajar ini terletak pada sejumlah fitur yang tersemat di dalam bahan ajar seperti adanya fitur pencarian, penanda halaman, ilustrasi berupa gambar, suara, video pembelajaran pada bagian materi dan tugas siswa. Penyematan sejumlah fitur tersebut merupakan hasil pengembangan bahan ajar. Sebelumnya, bahan ajar belum disertai sejumlah fitur yang disebutkan.

Hasil implementasi bahan ajar berjudul Mengenal Teks Cerita Fantasi untuk Siswa SMP/MTs Kelas VII berdasar hasil pekerjaan siswa diperoleh persentase sebesar $81,81 \%$ sehingga bahan ajar layak untuk digunakan. Sedangkan kelayakan bahan ajar dinilai melalui hasil validasi dan respon siswa diperoleh skor rata-rata sebesar 4,13 dengan persentase 82,64\% dan termasuk dalam kategori "baik". Maka, dapat disimpulkan bahan ajar digital berjudul Mengenal Teks Cerita Fantasi untuk Siswa SMP/MTs Kelas VII dinyatakan layak untuk digunakan dalam proses pembelajaran.

\section{Daftar Pustaka}

Andayani. (2015). Problema dan Aksioma: Dalam Metodologi Pembelajaran Bahasa Indonesia. Yogyakarta: Deepublish.

Atmaja, P. W. (2012). Vandaria Newsletter:Jalajahi Benua Elir. Jakarta: Artoncode.

Fajria, N. 2017. Pelaksanaan Pembelajaran Teks Cerita Fantasi di Kelas VII F SMP Negeri 8 Yogyakarta. Yogyakarta: Program Studi Pendidikan Bahasa Dan Sastra Indonesia Fakultas Bahasa dan Seni Universitas Negeri Yogyakarta. 
Gunawan, L. R. (2016). Tanggapan Guru Bahasa Indonesia Terhadap Problem Pembelajaran Sastra Dan Upaya Mengatasinya di SMP Kabupaten Sukoharjo. Pendidikan Bahasa Indonesia Fakultas Keguruan Dan Ilmu Pendidika Universitas Muhammadiyah Surakarta.

Harsiati, T dkk. (2016). Bahasa Indonesia. Jakarta: Kementrian Pendidikan dan Kebudayaan. Hasibuan, M. U. S. (2008). Revolusi Politik Kaum Muda. Jakarta: Yayasan Obor Indonesia. Mahsun, M. (2014). Metode Penelitian Bahasa. Jogjakarta: Ar-Ruzzmedi.

Mudlofir, A. (2011). Aplikasi Pengembangan Kurikulum Tingkat Satuan Pendidikan dan Bahan Ajar dalam Pendidikan Agama Islam. Jakarta : Rajawali Pers.

Prastowo, A. (2017). Menyusun Rencana Pelaksanaan Pembelajaran (RPP) Tematik Terpadu. Jakarta : Kencana.

Ratna, K. N. (2013). Teori, Metode, dan Teknik Penelitian Sastra. Yogyakarta: Pustaka Pelajar.

Rozak, A. (2014). Membaca Sastra Dalam Kurikulum 2013. Garut: Seminar Nasional APBI.

Rozalena, A dan Sri K. D. (2016). Panduan Praktis Menyusun Pengembangan Karier dan Pelatihan Karyawan. Jakarta: Raih Asa Sukses.

Sanjaya, W. (2017). Paradigma Baru Mengajar. Jakarta: Kencana.

Sugiyono. (2011). Metode Penelitian Kuantitatif, Kualitatif dan R\&D. Bandung: Alfabeta.

Tompo, B. (2016). Cara Cepat Membuat Buku Digital Android: Seri Tutorial Mulai Dasar Sampai Upload ke Playstore: Matsnuepa Publishing.

Various. (2011). Antologi Cerita Fantasi Terbaik 2011. Jakarta: Adhika Pustaka. 